\title{
SHORT COMMUNICATION \\ WOMEN IN AMAZONIAN ELASMOBRANCH RESEARCH: A TRIBUTE TO THE BRAZILIAN RESEARCHERS
}

\author{
NATASCHA WOSNICK ${ }^{*} \&$ ANA RITA ONODERA PALMEIRA-NUNES ${ }^{2}$ \\ ${ }^{1}$ Universidade Federal do Paraná. Departamento de Zoologia. Av. Cel. Francisco H. dos Santos, 100. CEP 83255- \\ 000. Curitiba, PR, Brasil. \\ ${ }^{2}$ Rede de Biodiversidade e Biotecnologia da Amazônia Legal. Universidade Federal do Maranhão. Laboratório de \\ Organismos Aquáticos. Avenida dos Portugueses 1966, Cidade Universitária do Bacanga, CEP 65080-805, São Luís, \\ MA, Brasil.
}

Corresponding author: n.wosnick@gmail.com

\begin{abstract}
RESUMO
Historicamente, mulheres foram excluídas do mundo científico e acadêmico. Foi apenas na segunda metade do século XX que elas tiveram acesso à educação científica e iniciaram suas carreiras profissionais, com baixa participação feminina na área de ciência e tecnologia e um enorme rastro de discriminação de gênero e preconceito. Atualmente as mulheres continuam lutando para vencer as barreiras impostas pela sociedade e cultura patriarcais, e inúmeras mudanças ainda são necessárias para se introduzir uma perspectiva de gênero na ciência e cada passo dado é uma vitória em direção à inclusão e reconhecimento. Aqui trazemos uma lista de mulheres que se engajaram na pesquisa de elasmobrânquios na região amazônica e dedicaram suas carreiras à pesquisa e conservação de tubarões e raias. Esperamos que a presente homenagem a estas mulheres fortes que pavimentaram nosso caminho possa inspirar jovens cientistas a fazerem o mesmo.

Palavras-chave: Chondrichthyes; Amazônia; gênero; ciência.
\end{abstract}

\section{ABSTRACT}

Historically, women have been excluded from the scientific and academic world. It was only in the second half of the twentieth century that women had access to scientific education and started their professional careers, with low female participation in science and technology and a trail of gender discrimination and prejudice. Nowadays women continue to continue to struggle to overcome the barriers imposed by patriarchal society and culture, and several changes are still needed to introduce a gender perspective in science, and every step taken is a victory towards inclusion and recognition. Here is a list of women who have engaged in elasmobranch research in the Amazonian region and dedicated their careers to improving knowledge of sharks and batoids. We hope that with this special edition we will not only be able to honor these strong women who have paved our way, but also to inspire young scientists to do the same.

Keywords: Chondrichthyes; Amazon; gender; science.

The history of women in science brings a trail of construction and resignification of social and cultural places already determined by prejudice and gender discrimination since its origin, present in patriarchal society and institutions until recently (Silva and Ribeiro 2014). In the fifteenth, sixteenth, and seventeenth centuries, a series of changes in society and science began, in which women's participation came to be accepted in a small and discreet manner, as a support to aristocratic fathers and husbands inserted in the scientific world (Leta 2003). In the eighteenth century, women's participation in science was restricted to cleaning and maintaining glassware, maintenance and updating of collections (without being considered curators) and scientific translations, being excluded from any scientific discussion (Leta 2003). Only in the second half of the twentieth century women gained more effective participation in scientific education, due to the need for human resources and the struggle for equal rights between genders (Leta 2003).

Rossi (1965) wrote one of the first articles published in scientific journals that addressed the issue of women's participation in Science and Technology, explaining the possible causes of the low representativeness, such as the priority given to marriage and motherhood, the professional choices influenced by parents, and biological and social 
differences between men and women. Subsequently, other studies on women's participation in S\&T were published, raising concerns such as lower productivity compared to men, low representation in leadership positions, less access to resources and lower wages (Leta 2003). These challenges have been overcome, albeit slowly, allowing women to stand out in the scientific and academic world (Schiebinger 2001).

Although the number of women in science and technology is growing, the representativeness is still low. Still, within the areas of natural science, marine biology has been standing out by the number of women developing research. However, much still remains to be done about introducing a gender perspective in science, a real adaptation of women in their workplaces, reframing each step to the end of the traditional "male career model" and the unintentional prejudice (Silva and Ribeiro 2014).

In Brazil, the elasmobranch research community has many women who are references in their fields and several young women are following their steps. As women in elasmobranch research, we come from a proud lineage of strong women who have made incredible contributions, most of the time under challenging circumstances. These women have paved the way for those of us who have come after them and provided inspiration to all of us. With this article, we present a brief highlight on the careers of a few female researchers to acknowledge their contributions to elasmobranch research developed at the Brazilian Amazonian coast (BAC) (Figure 1).

Currently, the Brazilian marine elasmobranch fauna comprises 168 species (91 sharks; 77 batoids), composing 10 orders, 33 families, and 75 genera (Rosa and Gadig 2014). Additionally, three families, four genera and six species of chimeras are also found in Brazilian waters, totaling 174 species of marine cartilaginous fishes distributed along the coast. Considering strictly freshwater stingrays, 42 species are currently recognized, composing 1 family and 5 genera (Silva and Loboda 2019).

Brazil occupies $47 \%$ of the South American area and has a coastline of approximately 8,500 $\mathrm{km}$, of which $35 \%$ comprise the BAC. BAC's geographical delimitation is between Oiapoque river in Amapá state and São Marcos bay in Maranhão state (Camargo and Isaac 2001), however, since the Amazonian chondrofauna extends to the Parnaíba's delta in Piauí state, this has been considered the BAC's limit in the present study (Aragão 2018). It is a region with a wide continental shelf $(\sim 330 \mathrm{~km})$ and very peculiar abiotic characteristics, such as

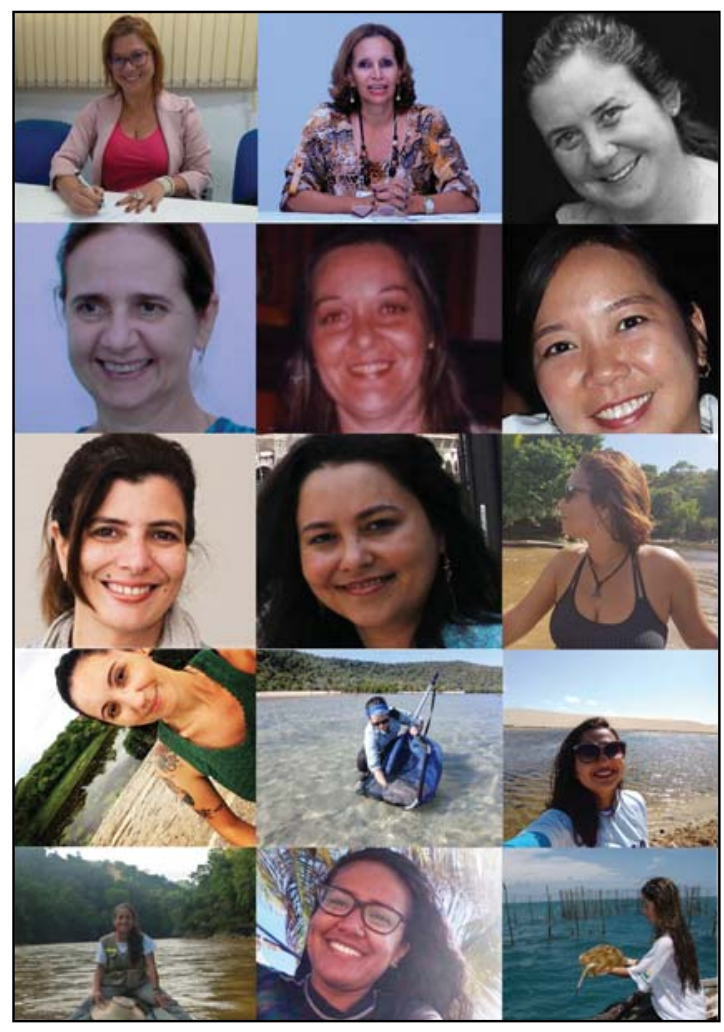

Figure 1. Women featured in this paper. First row - Zafira da Silva de Almeida, Rosangela Paula Teixeira Lessa, Patrícia Charvet; second row - Maria Lúcia Góes de Araújo, Victoria Judith Isaac Nahum, Akemi Shibuya; third row - Flavia Lucena Fredou, Raimunda Nonata Fortes Carvalho Neta, Cecile de Souza Gama; fourth row - Geórgia Maria de Oliveira Aragão, Ana Paula Barbosa Martins, Rafaela Maria Serra de Brito; fifth row - Viviana Márquez Velásquez ; Héllida Negrão Dias, Ana Rita Onodera Palmeira Nunes.

high annual precipitation (up to $3,300 \mathrm{~mm}$ ), high temperatures $\left(>20^{\circ} \mathrm{C}\right)$, low annual thermal variation, extensive tidal regime, discharge of several estuaries leading high levels of nutrients and organic matter. Still, BAC is home for one of the most extensive mangrove systems worldwide, providing shelter and nursery for countless species (ICMBio 2018). Northern Brazil has been identified as an important global elasmobranch conservation hotspot due to its high irreplaceability score (Dulvy et al. 2014).

Fishing in the region is predominantly artisanal (Carvalho-Neta and Almeida 2012), but surveys by researchers show that elasmobranch bycatch is one of the highest in Brazil, emphasizing the importance of studies in the BAC. Although full of natural beauty, the region poses great challenges for those who decide to venture into the forests and aquatic environments. Also, the accentuated climatic 
conditions and the region's low rate of development and poverty make conservation studies a challenge, as the needs of traditional communities must be met. Still, environmental conflicts in the region expose researchers to constant threats that need to be faced daily by men and women dedicated to scientific knowledge.

\section{Dr. Zafira da Silva de Almeida}

Zafira is one of the main references in Amazonian fish research, guiding several students who, like her, pursue an academic career in our country. Always showing leadership and charisma, she began her career in 1986 as an undergraduate student in Biological Sciences at Universidade Federal do Maranhão. Then she got a master's degree at Universidade Federal de Pernambuco, under the guidance of Dr. Veronica Fonseca-Genevois. In 2004, she got her Ph.D. at Universidade Federal do Pará, under the supervision of Dr. Victoria Judith Isaac Nahum. Her thesis aimed to determine the biological and socioeconomic aspects related to marine and estuarine fishery resources of Maranhão state. She has published several papers about Amazonian elasmobranchs, including Carcharhinus porosus, Sphyrna tiburo, Isogomphodon oxyrhynchus, Rhizoprionodon porosus, Urotrygon microphtalmum and Hypanus guttatus. She is currently the undergraduate prorector at Universidade Estadual do Maranhão, where she founded and directed the course of Biological Sciences. She is also a member of the Academy of Sciences of Maranhão, a professor at the Universidade Estadual do Maranhão and head of the Laboratory of Fisheries and Aquatic Ecology (LabPEA) at the same university. Currently, Zafira works to improve the fishing communities of Maranhão, as well as generating subsidies for the assessment of threatened fish species in the state. And since she has been always worked closely with the productive sector, Zafira had access to countless elasmobranch fisheries landings that provided subsidy to study several biological and economic aspects of artisanal fishing.

\section{Dr. Rosangela Paula Teixeira Lessa}

Rosangela is one of the most remarkable faces of the Brazilian Society for the Study of Elasmobranchs (SBEEL). She is an elasmobranch reference in Brazil that acts firmly in defense of sharks and rays. Because of that, she is a role model to all of us, but especially to women that dream to be a researcher in this field like her. Such is her outstanding contribution to elasmobranch research that a batoid was named in her honor, Gymnura lessae. Born and graduated in Rio Grande - RS (1977), the recently graduated oceanographer from Universidade Federal de Rio Grande left for France to pursue her master's and doctorate degrees at the Université de Bretagne Occidentale. In her Ph.D., supervised by Dr. Jacqueline Lahaye and Dr. Carolus Maria Vooren, Rosangela developed her research on Biology and Population Dynamics of Pseubatos horkelli on the continental shelf of Rio Grande do Sul. Upon returning in 1982, she bravely decided to look for new possibilities in the opposite extreme of the country, in São Luís do Maranhão. During that time, she carried out outstanding research in the Amazon region by participating in oceanographic cruises to discover the specific composition of coastal elasmobranch populations and to develop studies on their biology. In 1989, she joined the academic body from Universidade Federal Rural de Pernambuco, being a member of the Department of Fisheries and Aquaculture and head of the Marine Population Dynamics Laboratory (DIMAR) until nowadays. She was the representative of the Population Dynamics and Inventory Evaluation area from the REVIZEE Program, coordinator of taxon Chondrichthyes in the extinction risk assessments promoted by ICMBio and Chairman of the Pernambuco State Shark Incident Committee. She is also a founding member of SBEEL, her golden girl, and was president of the society between 2002-2004. Even though living in Recife (Pernambuco state), Rosangela still guides graduate students from Universidade Estadual do Maranhão. Not less important than the others, Rosangela is the greatest expert on Isogomphodon oxyrhynchus, and just about everything known about this Critically Endangered and endemic species of the Amazon coast has been discovered throughout her career.

\section{Dr. Patricia Charvet}

When it comes to South American elasmobranchs, Patricia is the one you should look for. Biologist graduated at Pontifícia Universidade Católica do Paraná, with a master's degree in Zoology from Universidade Federal do Pará and a Ph.D. in Biological Sciences from Universidade Federal da Paraíba, Patrícia has been working with elasmobranchs since undergraduate. Her first research aimed to characterize the morphological 
and functional aspects of dermal denticles in Rhizoprionodon lalandii, a species commonly fished along the Brazilian coast. Later she developed research in the state of Pará focusing on sawfishes and freshwater stingrays, working very hard at the field for her Ph.D. research at Xingu river, which made her a huge reference in the subject. Anyone who knows her personally is amazed by her ability to give talks and talent with languages, after all, she is familiar with more than six. Currently, she is the Shark Specialist Group Eastern South America Regional Vice-Chair - responsible for updating the IUCN Red List that helps to set conservation measurements at the international level for elasmobranchs threatened with extinction. Even though not currently living in the northern region, Patricia still is imperative for the understanding of endemic species of the Amazon coast, such as Fontitrygon colarensis.

\section{Dr. Maria Lúcia Góes de Araújo}

Freshwater stingrays? Maria Lúcia is the one you should call. She is an oceanologist from Universidade Federal do Rio Grande, with a master's degree in Freshwater and Inland Fisheries Biology from Instituto Nacional de Pesquisas da Amazônia and a Ph.D. in Biological Diversity from Universidade Federal do Amazonas. With a background like this, it's not difficult to understand why we have decided to honor her. She is brilliant and can be multipurpose, ranging from one area of knowledge to another quite distinct, such as histology and population dynamics. As an undergraduate, she gained experience in monitoring elasmobranch landings in southern Brazil. After that, she decided to specialize in Amazonian species, particularly freshwater stingrays from Medium Valleys at Negro and Tapajós rivers, focusing on the ecology of Paratrygon aiereba and reproductive aspects of Potamotrygon spp. She was also one of the first researchers in Brazil to keep captive freshwater stingrays and her knowledge has been essential to the physiological research currently carried out at the Universidade Federal do Amazonas and other institutions. Maria Lúcia did her postdoctoral research at Universidade Federal Rural de Pernambuco on Management and Conservation of Marine Fishing Resources, focusing on the Dasyatidae rays. Maria Lúcia is now a collaborative researcher at Universidade Federal de Sergipe.

\section{Dr. Victoria Judith Isaac Nahum}

Victoria is the face of the Amazon. When it comes to fisheries resources of the region, her name always pops up in our minds. She began her professional career in 1973 with a degree in Biological Sciences and specialization in Pathological Anatomy at Universidad de la Republica (Uruguay). In 1978, she started her masters in Biological Oceanography at Universidade de São Paulo, under the guidance of Dr. Anna Emilia Amato de Morais Vazzoler. Her dissertation focused on the reproduction of the teleost fish, Micropogonias furnieri. She later received a Ph.D. in Marine Sciences from the Institut Fuer Meereskunde (Germany). Her thesis aimed to evaluate fish growth estimation methodologies and was supervised by Dr. Daniel Pauly. After that, she held two postdocs, being one at the University of British Columbia and the other one at the University of Florida. Having life experience in many countries has made her familiar with several languages such as English, German and Spanish, and venturing into French and Hebrew. Her work on Amazonian fishery resources has provided and still generates - essential information on elasmobranch commercial capture and an important list about estuarine species from northern Brazil with their geographic distribution, which include 12 species of sharks and 21 of batoids. She is currently a professor at the Institute of Biological Sciences at the Universidade Federal do Pará and head of the Laboratory of Fishery Biology and Aquatic Resources Management at the same university.

\section{Dr. Akemi Shibuya}

Akemi devoted all his academic training to elasmobranchs, with oriental discipline and wisdom. She has a degree in Biological Sciences from the Universidade Federal do Amazonas and developed her master's research on Rhizoprionodon porosus feeding habits under the guidance of Dr. Ricardo de Souza Rosa at the Universidade Federal da Paraíba. In her doctorate, she worked with functional morphology of the feeding mechanisms in Myliobatoidei rays, mainly Potamotrygonidae of the Medium Valley of Negro river, under the guidance of Dr. Jansen Alfredo Sampaio Zuanon at the Instituto Nacional de Pesquisas da Amazônia. In the same period, she did a course on Elasmobranch Functional Morphology at Tokai University, Tokaidai (Japan), conducting research on Dasyatis matsubarai. Since then, she has been developing her postdoctoral research at the Universidade de São Paulo, and is currently developing another postdoctoral research 
at the Instituto Nacional de Pesquisas da Amazônia (INPA) on biology and conservation of freshwater stingrays.

\section{Dr. Flavia Lucena Fredou}

The management of pelagic species has a face, known as Dr. Fredou. At the beginning of career, she worked with a diversity of shark species, including Sphyrna lewini, Sphyrna tudes and Carcharhinus signatus. Flavia has also developed research on fishery production from the Amazon region, with focus on landings at the State of Pará. She graduated in Fishery Engineering at Universidade Federal Rural de Pernambuco, holds a master's degree in Biological Oceanography from Universidade Federal de Rio Grande and a Ph.D. in Modeling from the Center of Environmental Fisheries and Aquaculture Sciences (England). She also did her postdoc at Institut Pour la Recherche et Développement (France). She was the coordinator of Marine Fish Taxon at the Global Marine Species Assessment, a collaboration between the International Union for the Conservation of Nature, Conservation International and COABio (Brazilian Biodiversity Conservation Assessment - MMA), responsible for assessing species conservation status. As a member of the Tuna and Related Research Subcommittee, she represents Brazil at ICCAT, coordinating the Small Tunas group. She was also part of the Ecologically or Biologically Significant Marine Areas Description workgroup organized by the Convention on Biological Diversity. She is also a member of the World Ocean Assessment Pool of Experts (UN), a member of the IUCN Species Survival Commission, the IUCN Sciaenid Red List Authority and the IUCN Tuna \& Billfishes Specialist Group. Last but not least, she is a professor at Universidade Federal Rural de Pernambuco. The vast experience with fishing statistics and modeling makes her one of the most important researchers on pelagic fishes worldwide.

\section{Dr. Raimunda Nonata Fortes Carvalho Neta}

Raimunda is an artist and a biologist, as she holds a degree in Biology (UFMA, 2000) and another one in Fine Arts (UEMA, 1999). Her undergraduate research addressed the diet of Hypanus guttatus from Maranhão state under the guidance of Dr. Zafira da Silva de Almeida. Then, her master's research was focused on ecological aspects and ethnoknowledge of the Crab Island ichthyofauna, under the supervision of Dr. Antonio Carlos Leal de Castro. During her Ph.D., she used biomarkers and artificial intelligence to monitor the São Luís port complex, supervised by Dr. Ana Lúcia Abreu-Silva. She is currently coordinating the Laboratory of Aquatic Organism Biomarkers and leading researches mainly on fish contamination, fishery production and environmental education.

\section{Dr. Cecile de Souza Gama}

Cecile is a specialist researcher in diversity and ecology of freshwater stingrays from Amapá state, far Northern Brazil. She graduated at Universidade Federal do Rio de Janeiro, then obtained a master's degree in Zoology from Universidade Federal de Juiz de Fora and a Ph.D. in Zoology from Universidade Federal da Paraíba, under the guidance of Dr. Ricardo de Souza Rosa. Despite her extensive experience in fish trophic ecology, she only became specialized in elasmobranchs during her Ph.D., being an example for all those who decide to pursue a career in this field later on. She is currently a researcher at the Instituto de Pesquisas Científicas e Tecnológicas do Estado do Amapá - IEPA, where she continues to develop research on freshwater species and the anthropic impacts on the Amazonian fish communities.

\section{Dr. Geórgia Maria de Oliveira Aragão}

Georgia recently faced the challenge of completing the Ph.D. while living motherhood. She understands like no one about traditional communities and elasmobranch landings from the Amazonian artisanal fleet. Her undergraduate study was at Universidade Federal do Piauí. She then got her master's degree at Universidade Federal de Santa Catarina and recently defended her doctorate thesis at Universidade Federal do Paraná. Even though she is linked to a university in Southern Brazil, Georgia researched the elasmobranch landings at the Environmental Protection Area of delta do Parnaíba, a region of extreme importance for the conservation of fish in general, as well as at the south boundary of the BAC. Georgia currently works as a researcher at the Instituto Piauiense de Pesquisa Aplicada para a Gestão Pública.

\section{Dr. Ana Paula Barbosa Martins}

Ana Paula researchs fishery productive chain aspects like no one else. During her undergraduate degree in Biological Sciences at Universidade Federal do Maranhão, she researched fish ecology of surf 
zones. In her master's degree, under the orientation of Dr. Jorge Luiz Silva Nunes, she researched aspects of the productive chain and conservation status of sharks from the Amazon coast. Her work has been prominently featured and was published in Plos One recently. Besides, during her masters, Ana developed several parallel studies, which led to many papers that have already been published. Recently, she got her PhD at James Cook University (Australia), where, through the supervision of Dr. Colin Simperdorfer, she studied ecological aspects of coastal elasmobranchs. Although not currently living or working in Brazil, Ana had and still has great value and influence, being a role model for students from the institution where her career was originated and to other Brazilian students.

\section{MSc. Rafaela Maria Serra de Brito}

Nowadays, the growing need for environmental awareness and education on traditional communities is making Rafaela one of the most important women working on social and environmental conflicts in the State of Maranhão. After the degree in Oceanography from the Universidade Federal do Maranhão, she obtained her master's degree in Ecology and Conservation at Universidade Estadual da Paraíba - UEPB (2015) by studying ecological aspects of Rhizoprionodon porosus and the ethnobiological aspects of elasmobranch fishing on the Amazon coast, with guidance of Dr. Antonio Carlos Leal de Castro and Dr. José da Silva Mourão. Later on, she spent five years at the Superintendency of Biodiversity and Protected Areas of the Secretaria de Estado do Meio Ambiente e Recursos Naturais, advising the state on biodiversity activities and conservation units management. In addition to her charisma and dedication, Rafaela knows how to mediate social conflicts and develop practices of sustainable use of resources, always considering the well-being and insertion of traditional communities. She is now a member of the Maranhão Elasmobranch Research Group (GEEM) and a member of the Amares Institute, conducting research on elasmobranch artisanal fishing, and environmental education on the state's marine resources.

\section{MSc. Viviana Márquez Velásquez}

Is she Colombian with a Brazilian heart or Brazilian with Colombian accent? We don't know for sure, but it doesn't matter, because Viviana is a woman full of energy and joy, that spreads to everyone around her. Graduated in Biology at the Universidad de Antioquia in the city of Medellín (Colombia), she developed her research on the biology of Urotrygon sp. from the south of the Colombian Pacific. With a bold decision, she left Colombia to move to Brazil and then got her master's degree at Universidade Federal da Paraíba. Her master research aimed to determine the ecological importance of Potamotrygon magdalenae in a trophic network of the Colombian Andes, under the orientation of Dr. Ricardo de Souza Rosa and Dr. Andrés Felipe Navia. At present, she is a Ph.D. student at Universidade Federal da Paraíba, working on the structural and functional roles of fish species within trophic networks and its consequences towards biodiversity conservation. Viviana is a member of Fundación Squalus, the Colombian Foundation for Elasmobranch Research and Conservation. Besides being a researcher, she spends the rest of her energy and time participating in professional water polo competitions and with plenty of friends that she has made in Brazil and around the world.

\section{BSc. Héllida Negrão Dias}

Hands-on, dedication and focus define Héllida, as well as her incredible and natural talent in preparing elasmobranch arcades that are used for teaching purposes. She has a degree in Biology from Instituto Federal de Educação, Ciência e Tecnologia do Pará and a technical-vocational fisheries degree at the same institution. She is currently an Oceanography student at the Universidade Federal do Maranhão, under the guidance of Dr. Jorge Luiz Silva Nunes. She is part of the Aquatic Organisms Laboratory (LabAqua) and a member of the Maranhão Elasmobranch Research Group (GEEM). Héllida developed an ethnobiology research focusing on batoids in a fishing community of Pará, contributing to a better understanding of elasmobranchs from that region. She currently works on dietary aspects of Hypanus guttatus, but also investigates the dietary patterns of endemic Amazonian species such as Fontitrygon geijskesi and Isogomphodon oxyrhynchus.

\section{MSc. Ana Rita Onodera Palmeira Nunes (without her knowledge)}

Ana Rita plays a key role in the access of traditional knowledge on batoids from Pará state. Wherever she goes, Ana Rita captivates people. Owner of a unique personality and a giant heart, 
she helps everyone without expecting anything in return, always winning admirers for her charisma, dedication, and intelligence. Graduated in Biological Sciences at the Centro Universitario de Brasília, Ana wasn't defeated by the fact that there are no elasmobranchs in the Federal District and developed her research on the biology of Hypanus marianae caught in the artisanal fishing of Ceará, oriented by Dr. Getulio Rincon. For her master's degree, she moved to João Pessoa, where she studied the reproductive aspects of Hypanus guttatus. Ana has also worked in Recife with the reproductive biology of oceanic sharks and educating people about the shark attacks which occurred at the metropolitan region of Recife, as well as ways to avoid negative interactions with sharks in the region. Her knowledge on batoids is essential to the ongoing activities in the Aquatic Organisms Laboratory from Universidade Federal do Maranhão. Devout of Holy Mary and very religious, Ana is an example of faith and perseverance and proves to everyone that religion and science can walk side by side. She is one of the most active members of SBEEL, having participated in the organization of several meetings and most recently of the Sharks International Conference 2018 that was held in João Pessoa. With her vast experience, she has taught and continues to teach us all in how to organize scientific events, doing it like no one else. Recently she started her Ph.D. at the Universidade Federal do Maranhão, where she will study the genetic aspects of the rays of the genus Fontitrygon."

This selection is only part of our amazons, and they represent all those who have not been cited. We know that the number of women who have fought and/or continue to fight in defense of elasmobranchs is much higher. Many may have gone unnoticed for the academy, but they were certainly essential in their areas of engagement, even though they received no honors or trophies. With so many examples of strong, hardworking, and obstinate women, we encourage all girls who begin their research on elasmobranchs to continue this list of Brazilian women in science, unfolding their work in this fertile Amazonian terrain left by all the Victoria amazonica cited above. Thank you for making difficult choices so many times, for taking so much risk and for persevere in spite of the work restrictions and gender discrimination. May the 21 st century be marked by the growing appreciation and presence of women in science, with a real adaptation of women in their workplaces in a new and fair "female carreer model".

\section{ACKNOWLEDGEMENTS}

We would like to thank Ingrid Hyrycena dos Santos for English proofreading and help with the manuscript, and the anonymous reviewers for their important collaboration. We would also like to thank all the women who work on elasmobranch research in Amazon and that we are not aware of yet. Keep up the great work.

\section{REFERENCES}

ARAGÃO, G. M. O. A. 2018. A comunidade de elasmobrânquios marinhos na APA do Delta do Parnaíba e sua relação com a pesca artesanal. Doutorado em Sistemas Costeiros e Oceânicos. Universidade Federal do Paraná, UFPR, Brasil.

CAMARGO, M.; ISAAC, V.J. 2001. Os peixes estuarinos da região norte do Brasil: lista de espécies e considerações sobre sua distribuição geográfica. Boletim do Museu Paraense Emílio Goeldi. Série Zoologia, 17(2):133-157.

CARVALHO-NETA, R. N. F.; ALMEIDA, Z.S. 2012. Recursos pesqueiros do litoral maranhense: pesca e biomonitoramento. Plural, 4: 92-127.

DULVY, N.K.; HARRISSON, L.R.; CARLSON, J.K.; DAVIDSON, L.N.K.; FORDHAM, S.V.; FRANCIS, M.P.; POLLOCK, C.M.; SIMPFENDORFER, C.A.; BURGESS, G.H.; CARPENTER, K.E.; COMPAGNO, L.J.V.; EBERT, D.A.; GIBSON, C.; HEUPEL, M.R.; LIVINGSTONE, S.R.; SANCIANGCO, J.C.; STEVENS, J.D.; VALENTI, S.; WHITE, W.T. 2014. Extinction Risk and Conservation of the World's Sharks and Rays. Elife, 3:e00590: 1-34.

INSTITUTO CHICO MENDES DE CONSERVAÇÃO DA BIODIVERSIDADE. 2018. Atlas dos Manguezais do Brasil. Brasília: Instituto Chico Mendes de Conservação da Biodiversidade, $176 \mathrm{p}$.

LETA, J. 2003. As mulheres na ciência brasileira: crescimento, contrastes e um perfil de sucesso. Estudos avançados, 17(49):271-284.

ROSA, R.S.; GADIG, O. B. F. 2014. Conhecimento da diversidade dos Chondrichthyes marinhos no Brasil: a contribuição de José Lima de Figueiredo. Arquivos de Zoologia, 45: 89-104.

ROSSI, A. S. 1965. Women in Science: Why so 
Few? Social and Psychological Influences Restrict Women's Choice and Pursuit of Carrers in Science. Science, 148: 1196-1202.

SCHIENBINGER, L. 2001. O feminismo mudou a ciência? Bauru, Edusc.

SILVA, F. F.; RIBEIRO, P. R. C. 2014. Trajetórias de mulheres na ciência: "ser cientista" e "ser mulher". Ciênc. Educ., 20(2):449-466.

SILVA, J.P.C.B. DA; LOBODA, T.S. 2019. Potamotrygon marquesi, a new species of neotropical freshwater stingray (Potamotrygonidae) from the Brazilian Amazon Basin. Journal of Fish Biology, 95(2):594-612. doi: 10.1111/jfb.14050. 